\title{
Semen characteristics and seminal oxidative status of four breeds of rabbit in South west, Nigeria
}

\author{
Olatunji Abubakar Jimoh ${ }^{1,2^{*}}$ and Emmanuel Olubisi Ewuola ${ }^{1}$
}

\begin{abstract}
Background: Within the rabbit population in South West of Nigeria, four exotic breeds of rabbits consisting of Fauve de Bourgogne, Chinchilla, British Spot, and New Zealand White were evaluated for their reproductive response. This investigation was carried out within July and August, when the least temperature-humidity index (THI) (ranged between 23.41 and 25.30) is observed in Ibadan, South West, Nigeria, which depicts the highest thermal comfort in the study area. Thirty bucks per breed, housed individually and randomly allotted to experimental units, were used for this study. All bucks were made to serve an artificial vagina, libido was evaluated, and the collected ejaculates were assessed for semen characteristics, seminal biochemical parameters, and oxidative stress indices weekly for 4 weeks. Two ejaculates per buck were collected weekly. The first ejaculate for spermiogram and the second ejaculate was centrifuged at 4000 rpm for 15 min to separate seminal plasma and used for biochemical analysis using standard procedures.

Result: The result obtained revealed that sexual urge (reaction time) in the four breeds was similar statistically. British Spot and New Zealand White breeds despite recording a lower semen volume had apparently higher mass motility, individual sperm motility, and significantly higher $(P<0.05)$ sperm concentration compared with the other breeds. Genetic differences in breeds were evident in most oxidative stress markers, except for the total antioxidant activity of seminal fluid. New Zealand White had the highest antioxidant enzyme activity.

Conclusion: New Zealand White had the best oxidative status among the four breeds, and this enhanced its semen quality parameters among the rabbit breeds.
\end{abstract}

Keywords: Spermiogram, Seminal plasma, Rabbit breeds, Thermal comfort, Oxidative stress

\section{Background}

The rabbit is more tolerant to low temperatures than to high temperatures; thus, if the environmental temperature is above $25-30{ }^{\circ} \mathrm{C}$, the behaviour and several physiological changes reduce productivity. Comparative study on breeds of rabbit for production superiority will lead to the discovery of breed to be considered for improved breeding, and crosses between these breeds and with other rabbit breeds will improve the production efficiency of rabbit breeds with less production efficiency (El-Sheikh \& Seleem, 2010). Abd El-Azim and El-kamash (2015) reported that

\footnotetext{
* Correspondence: abubakarjimoh2011@gmail.com

${ }^{1}$ Animal Physiology Laboratory, Department of Animal Science, University of Ibadan, Ibadan, Oyo State, Nigeria

${ }^{2}$ Agricultural Technology Department, Federal Polytechnic Ado-Ekiti, Ado Ekiti, Ekiti State, Nigeria
}

breed of rabbit bucks differ in reaction time, semen $\mathrm{pH}$, semen density, semen colour, mass motility and advanced motility. Seminal plasma also contains other particles of different sizes which affect the spermatozoa behaviour during the transit along the female reproductive tract (Castellini, 2008). Variation in the seminal characteristics contribute to the large variability in semen quality traits (Alvariño, 2000), it is important to evaluate seminal inclusions to improve semen output.Oxidative stress results from increased production of free radicals and reactive oxygen species and a decrease in antioxidant defense (Trevisan, Browne, Ram, Muti, \& Freudenheim, 2001; Williams, Kronfeld, Hess, Saker, \& Waldron, 2002). Ganaie, Shanker, Bumla, Ghasura, and Mir (2013) reported that oxidation is essential to nearly all cells in the body to provide energy for vital functions. Approximately 
95 to $98 \%$ of the oxygen consumed is reduced to water during aerobic metabolism, but the remaining fraction may be converted to oxidative by-products-reactive oxygen species, that may damage the DNA of genes and contribute to degenerative changes (Ganaie et al., 2013). Studies have shown that antioxidants are uniquely different from each other, and each has a specific function in the body. It has been suggested that reactive oxygen species (ROS) and lipid peroxide products in various clinical diagnoses of infertility are associated with high oxidative stress and whether any group of infertile animal is more likely to have high seminal oxidative stress. ROS play an important role in sperm physiological functions, but elevated levels of ROS or normal cell functions and integrity of cell structures may be broken via considerable reactivity of ROS. The body system of animals has enzymatic, e.g. superoxide dismutase, catalase, glutathione peroxidase, and non-enzymatic, e.g., vitamin $\mathrm{E}$ antioxidant mechanisms that work as a scavenger for this harmful ROS. Radical scavenging antioxidants are consumed by the increased free radical activity associated with several conditions, and the total antioxidant response has been used to indirectly assess the free radical activity (El-Tohamy, Kotp, El-Nattat, Amira, \& Soliman, 2012). The contributions of thermal discomfort (heat stress) to infertility in rabbits via oxidative stress necessitated investigation to assess the reproductive performance and seminal oxidative stress markers of four exotic breeds of rabbit at the least thermal discomfort condition in Ibadan, South west, Nigeria. It is therefore important to determine and document the semen characteristics as well as the oxidative status of semen ejaculates produced by rabbit bucks at their peak of thermal comfort.

\section{Methods}

\section{Experimental site}

The research was carried out at the rabbit unit of the Teaching and Research Farm and the Animal Physiology Laboratory, Department of Animal Science, both of the University of Ibadan, Ibadan, South west, Nigeria. They are situated in the rainforest agro-ecological zone of Nigeria, between Lat. $7^{\circ} 27^{\prime}$ 18.74" $\mathrm{N}$ and $7^{\circ} 27^{\prime} 19.17^{\prime \prime} \mathrm{N}$ and Long. $3^{\circ} 53^{\prime}$ 13.98" $\mathrm{E}$ and $3^{\circ} 53^{\prime} 32.69^{\prime \prime}$ E. The average temperature are $22.87 \pm 3.92{ }^{\circ} \mathrm{C}$ and $34.57 \pm 4.01{ }^{\circ} \mathrm{C}$, rainfall $184.85 \pm 4.82 \mathrm{~mm}$ and $8.03 \pm 0.21 \mathrm{~mm}$, and relative humidity $87.20 \pm 3.19 \%$ and $63.06 \pm 5.28 \%$, during the dry and wet season, respectively. The study was approved by our institutional committee on the care and use of animals for research.

\section{Experimental animals, design and management}

Four exotic breeds of adult rabbit 10-14 months old with an average weight of $1245 \pm 30.56 \mathrm{~g}$ consisting of
Fauve de Bourgogne, Chinchilla, British Spot and New Zealand White. The bucks used for the study were 1218 months old with an average weight of $1826 \pm 8.35 \mathrm{~g}$. At the commencement of the trial, animals were confirmed to be of good health status, without abnormalities and conform to the breed categorization.

This experiment was carried out within July and August, when least THI is observed (range between 23.41 and 25.30) in the experimental site as reported by Jimoh and Ewuola (2018). Temperature and relative humidity of the rabbitry microclimate was recorded at 08:00 $\mathrm{h}$ every morning and 16:00 $\mathrm{h}$ in the evening during the study period using a thermohygrometer. The ambient temperature and relative humidity were used to compute the temperature-humidity index. Readings were taken daily. The temperature-humidity index (THI), an indicator of thermal comfort level for animals in an enclosure, was calculated as modified by Marai et al. (2001) and given as follows:

$$
\mathrm{THI}=t-[(0.31-0.31 \times \mathrm{RH} t-14.4)]
$$

where $\mathrm{RH}=$ relative humidity $/ 100$ and $t=$ ambient temperature.

The values of THI obtained for rabbit are classified as follows:

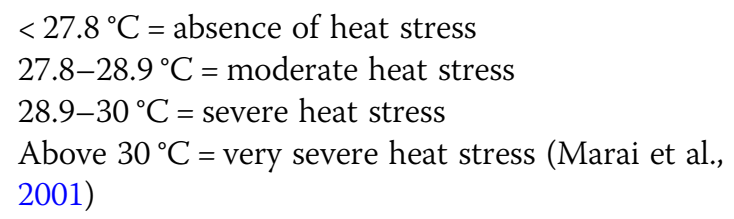

In the morning, the THI of July and August were 24.82 and $24.05{ }^{\circ} \mathrm{C}$, respectively, and the afternoon THI for July and August were 30.50 and $26.05{ }^{\circ} \mathrm{C}$, respectively. The average monthly THI for July and August were 27.66 and 25.05 , respectively.

Thirty bucks per breed were used for this study. Animals were housed individually and allotted randomly into experimental units. The experimental design was a completely randomised design. The animals were fed 5\% of their bodyweight, with diets containing crude protein $17.05 \%$, digestible energy $2592.06 \mathrm{Kcal} / \mathrm{kg}$, crude fibre $10.02 \%$, calcium $0.45 \%$ and phosphorus $0.21 \%$. Fresh water was made available to the animals always. Other routines and periodic management practices necessary for rabbit production were carried out. All bucks were used for assessment of semen characteristics, seminal biochemical parameters and oxidative stress indices.

\section{Semen characteristics}

Adult males were trained to serve an artificial vagina (designed and constructed for rabbits), two weeks prior 
to the experimental period, and two ejaculates per male were collected weekly, with an interval of 3-4 days between successive ejaculation over a period of 4 weeks from all males within the experiment. The first ejaculate for spermiogram and the second ejaculate were centrifuged at $4000 \mathrm{rpm}$ for $15 \mathrm{~min}$ to separate seminal plasma and stored at $-20{ }^{\circ} \mathrm{C}$, until further analysis. Briefly, libido was measured in terms of reaction time in seconds and was estimated from the time the doe was placed inside the buck's cage up to the point when the buck ejaculated (Daader, Gabr, \& Seleem, 1999). Semen volume for each buck was measured using tuberculin syringe to the nearest $0.1 \mathrm{ml}$. For mass motility, a drop of fresh semen was placed on a clean glass slide and examined with a microscope under $\times 10$ objective lens to determine mass motility. The mass motility was scored subjectively according to the intensity of the wave motion seen in the medium by the collective activities of spermatozoa, from the absence of wave motion $(+)$ to very turbulent motions $(+++)$. For individual sperm motility, a drop of semen with the aid of a micropipette was placed on a pre-warmed microscope slide and a drop of the diluent sodium citrate was added as may be required before it was covered with a glass cover slip and examine at a magnification of $\times 400$. The percentage of progressively motile spermatozoa was estimated, and the score is subjectively between 0 and 100. At least five microscopic fields were examined for each semen sample. The sperm concentration was measured by the direct sperm cell count method, using an improved Neubauer haemocytometer slide. Formal saline (1\%) was used to dilute the semen $(v / v)$ to immobilize the cells and make an enumeration of the sperm cells easier. The diluted semen was then charged on each of two chambers of the haemocytometer slide using a micropipette. The charged haemocytometer was placed on the microscope at a magnification of $\times 400$. The concentration of spermatozoa per volume was determined using the formula $C=$ $32,000 \times N \times D$, where $C$ is the concentration of the sperm cell per milligram of the semen, $N$ is the number of spermatozoa counted and $D$ is the dilution rate.The structural membrane integrity of spermatozoa is an assay of the livability of spermatozoa. Thus, it was determined by live to dead ratio of sperm cells. It involved adding a drop of the staining solution Nigrosin-Eosin on a clean slide and a drop of undiluted semen, mixed gently to prepare a smear. The slide was air-dried and examined with a microscope at $\times 400$ magnification. The functional membrane integrity was determined in semen samples in a 1:10 dilution of hypo-osmotic solution $75 \mathrm{mOsmol} / \mathrm{L}$ (Moce, Vicente, Lavara, Lavara, \& Marco-Jiménez, 2004). To a warm 1-ml swelling solution in a closed Eppendorf tube at $37{ }^{\circ} \mathrm{C}, 0.1-\mathrm{ml}$ liquefied semen was added and mixed gently within the tube. The mixture was kept at $37^{\circ} \mathrm{C}$ for at least $30 \mathrm{~min}$ and sperm cells examined at $\times 400$ magnification. The swelling of the sperm cell was identified with the changes in the shape of the tail. Counting in duplicate, the number of swollen cells in a total of 200 spermatozoa was counted and expressed as a percentage. The total motile sperm cell was calculated as the product of sperm concentration/milligram and percentage motility of semen sample per animal. Total live sperm cell was obtained by a multiple of sperm concentration per milligram and percentage livability.

\section{Seminal biochemical indices}

Seminal biochemical parameter values were determined using spectrophotometric procedure using Randox commercial assay kits. Total protein, according to Lowry, Rosebrough, Farr, and Randall (1951), glucose and total cholesterol concentration were determined as described by Lindner and Mann (1960). The spectrophotometry was used to determine sodium, chloride, phosphorus, magnesium and potassium contents of the samples.

\section{Seminal oxidative status}

Determination of seminal total antioxidant capacity activities was carried out according to (Koracevic, Koracevic, Djordjevic, Andrejevic, \& Cosic, 2001). The reactive mixture contained $0.5 \mathrm{~mL}$ of a $(10 \mathrm{mmol} / \mathrm{L})$ Na-Benzoate, $0.2 \mathrm{~mL}$ of $\mathrm{H}_{2} \mathrm{O}_{2}(10 \mathrm{mmol} / \mathrm{L}), 0.49 \mathrm{~mL}$ of phosphate buffer $(100 \mathrm{mmol} / \mathrm{L}, \mathrm{pH}=7.4)$ (prepared by mixing $19.5 \mathrm{~mL}$ of $\mathrm{KH}_{2} \mathrm{PO}_{4}(100 \mathrm{mmol} / \mathrm{L})$ with $80.5 \mathrm{~mL}$ of $\mathrm{Na}_{2} \mathrm{HPO}_{4}(100 \mathrm{mmol} / \mathrm{L})$, then adjusted the $\mathrm{pH}$ to 7.4) and $0.2 \mathrm{~mL}$ of Fe-EDTA complex $(2 \mathrm{mmol} / \mathrm{L})$ (prepared freshly by mixing equal volumes of EDTA $(2 \mathrm{mmol} / \mathrm{L})$ and ammonium ferrous sulfate $(2 \mathrm{mmol} / \mathrm{L})$, then left to stand at $25^{\circ} \mathrm{C}$ for $60 \mathrm{~min}$ ). Ten microliters of the blood serum was added to the latter reactive mixture and was incubated at $37^{\circ} \mathrm{C}$ for $60 \mathrm{~min}$. Finally, $1 \mathrm{~mL}$ glacial acetic acid $(20 \mathrm{mmol} / \mathrm{L})$ and $1 \mathrm{~mL}$ thiobarbituric acid $(0.8 \% \mathrm{w} / \mathrm{v}$ in $100 \mathrm{~mL}$ of $50 \mathrm{mmole} / \mathrm{L} \mathrm{NaOH}$ ) was added and the absorbance at $532 \mathrm{~nm}$ was measured spectrophotometrically after incubation at $100{ }^{\circ} \mathrm{C}$ for $10 \mathrm{~min}$. Total antioxidant capacity was calculated according to the following formula:

$$
\text { TA capacity }(\mathrm{mmol} / \mathrm{L})=(\mathrm{CUA})(K-A) /(K-\mathrm{UA})
$$

where (CUA) is the concentration of the uric acid $(\mathrm{mmol} / \mathrm{L}), K$ is the absorbance of the control $(\mathrm{K} 1-\mathrm{K} 0)$, $A$ is the absorbance of the sample (A1-A0) and $\mathrm{UA}$ is the absorbance of the uric acid solution (UA1-UA0).

Glutathione peroxidase activity is estimated as described by Rotruck et al. (1973) and Ellman's (1959). Briefly, the sample was added to $0.5 \mathrm{ml} 0.4 \mathrm{M}$ buffer (pH 7.0), $0.2 \mathrm{ml}$ enzyme source, $0.2 \mathrm{ml} 2 \mathrm{mM} \mathrm{GSH}$, and 
$0.1 \mathrm{ml} 0.2 \mathrm{mM} \mathrm{H}_{2} \mathrm{O}_{2}$ and incubated at room temperature for $10 \mathrm{~min}$ along with a control tube containing all reagents except enzyme source. The reaction was arrested by adding $0.5 \mathrm{ml}$ of $10 \%$ trichloroacetic acid TCA centrifuged at $4000 \mathrm{rpm}$ for $5 \mathrm{~min}$, and the GSH content in 0.5 $\mathrm{ml}$ of supernatant was estimated. The activity expressed as microgram of GSH consumed $/ \mathrm{min} / \mathrm{mg}$ protein.

Catalase activity is estimated by Beers and Sizer (1952) method. The assay system contains $1.9 \mathrm{ml}$ and $0.05 \mathrm{M}$ buffer ( $\mathrm{pH} 7.0$ ) and $1.0 \mathrm{ml}$ and $0.059 \mathrm{M} \mathrm{H}_{2} \mathrm{O}_{2}$. The reaction is initiated by addition of $0.1 \mathrm{ml}$ enzyme source. The decrease in absorbance is monitored at $1 \mathrm{~min}$ interval for $5 \mathrm{~min}$ at $240 \mathrm{~nm}$, and the activity is expressed as nanomoles of $\mathrm{H}_{2} \mathrm{O}_{2}$ decomposed $/ \mathrm{min} / \mathrm{mg}$ protein. Serum lipid peroxidation was determined using thiobarbituric acid assay according to Ohkawa, Ohishi, and Yagi (1979).

\section{Statistical analysis}

Data obtained in this study was subjected to descriptive statistics and analysis of variance of the general linear model procedure, and significant effects were detected with a confidence level of 95\%. The new Duncan multiple range test was used to separate means.

The statistical model is the following:

$$
Y_{\mathrm{ijl}}=\mu+B_{i}+e_{\mathrm{ijl}}
$$

where $Y_{\mathrm{ijl}}$ represents the value of semen characteristics, biochemical parameters and oxidative status measured in the $l$ th animal, $\mu$ is the overall mean for each character, $B_{i}$ is the fixed effect of $i$ th breed with four levels ( $i=$ Fauve de Bourgogne, Chinchilla, British Spot and New Zealand White) and $e_{\mathrm{ijl}}$ is the random residual effect.

\section{Results}

Reaction time and semen characteristics of four breeds of rabbit are presented in Table 1. Libido, sperm mass motility and motility were not significantly $(p>0.05)$ affected by breeds of rabbit. However, the semen volume of Chinchilla was significantly $(p<0.05)$ higher than that of British Spot and New Zealand White. British Spot and New Zealand White had similar semen volume with Fauve de Bourgogne rabbits. Sperm concentration, total live spermatozoa of British Spot and New Zealand White were significantly $(p<0.05)$ higher than that of Chinchilla rabbits. Fauve de Bourgogne rabbits had similar values with other breeds. The total motile spermatozoa of New Zealand White was significantly $(p<0.05)$ higher than Chinchilla rabbits. Fauve de Bourgogne and British Spot had similar total motile sperm with Chinchilla and New Zealand White rabbits.

The structural and functional spermatozoa membrane integrity of four exotic breeds of rabbit buck is presented in Fig. 1. The four breeds had normal spermatozoa structural membrane integrity ranging from 98.01 to $99.28 \%$. The sperm functional membrane integrity of the breeds is $69.65 \%, 70.55 \%, 72.78 \%$, and $69.8 \%$ for Fauve de Bourgogne, Chinchilla, British Spot and New Zealand White, respectively.

The seminal biochemistry of four exotic breed of rabbit buck is presented in Table 2. Seminal glucose, cholesterol, magnesium, potassium and chloride were not significantly $(p>0.05)$ influenced by breeds of rabbit. However, the seminal protein of British Spot rabbit was significantly $(p<0.05)$ higher than New Zealand White, but both were not significantly $(p>0.05)$ different from Fauve de Bourgogne and Chinchilla rabbit. Seminal sodium of Fauve de Bourgogne, New Zealand White and British Spot rabbits were significantly $(p<0.05)$ higher than Chinchilla rabbits. Seminal phosphorus of Fauve de Bourgogne and Chinchilla were statistically similar, but both were significantly $(p<0.05)$ higher than seminal phosphorus of British Spot and New Zealand White.

The seminal oxidative status of four exotic breeds of rabbit bucks is shown in Table 3. Rate of seminal lipid peroxidation in British Spot and New Zealand White are similar but were significantly $(p<0.05)$ higher than Fauve de Bourgogne bucks. However, the rate of seminal lipid

Table 1 Libido and semen characteristics of four exotic breeds of rabbit

\begin{tabular}{|c|c|c|c|c|c|c|}
\hline Parameters & Fauve de Bourgogne & Chinchilla & British Spot & New Zealand White & SEM & $p$ value \\
\hline Libido (reaction time in seconds) & 6.13 & 5.40 & 5.70 & 7.50 & 0.54 & NS \\
\hline Volume (ml) & $0.55^{\mathrm{ab}}$ & $0.70^{\mathrm{a}}$ & $0.41^{\mathrm{b}}$ & $0.34^{\mathrm{b}}$ & 0.04 & * \\
\hline Mass activity (\%) & 89.00 & 83.33 & 93.33 & 95.33 & 2.00 & NS \\
\hline Motility (\%) & 82.63 & 84.60 & 88.30 & 85.00 & 1.27 & NS \\
\hline Sperm concentration ( $\times 10^{8} / \mathrm{mL}$ spermatozoa) & $19.7^{\mathrm{ab}}$ & $16.91^{\mathrm{b}}$ & $23.68^{\mathrm{a}}$ & $22.78^{\mathrm{a}}$ & 2.49 & * \\
\hline Total motile sperm cells (× $10^{8} / \mathrm{mL}$ spermatozoa) & $16.75^{\mathrm{ab}}$ & $15.90^{\mathrm{b}}$ & $19.48^{\mathrm{ab}}$ & $21.98^{\mathrm{a}}$ & 2.22 & * \\
\hline Total live spermatozoa ( $\times 10^{8} / \mathrm{mL}$ spermatozoa) & $19.52^{\mathrm{ab}}$ & $16.81^{\mathrm{b}}$ & $22.53^{\mathrm{a}}$ & $24.06^{\mathrm{a}}$ & 2.51 & * \\
\hline
\end{tabular}

Means in the same row with different superscript letters are significantly $(p<0.05)$ different SEM standard error of mean, NS not significant $(p>0.05)$

*Significant difference $(p<0.05)$ 


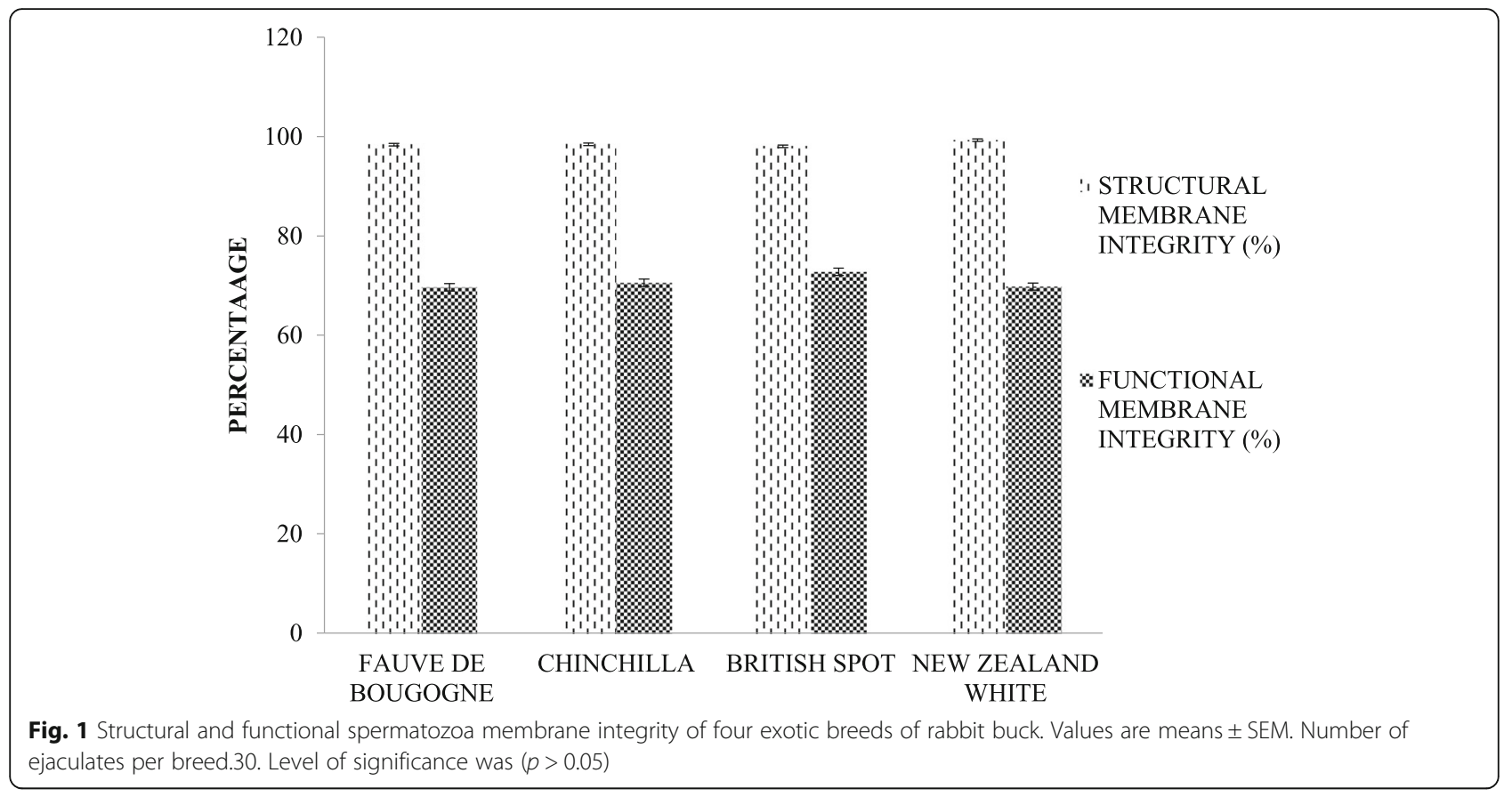

peroxidation in Chinchilla is not significantly $(p>0.05)$ different from other breeds.

Seminal antioxidant activity was not significantly $(p>0.05)$ affected by breeds of rabbit examined. Seminal superoxide dismutase activity in New Zealand White rabbits was significantly $(p<0.05)$ higher than that of Chinchilla; however, Fauve de Bourgogne and British Spot had statistically $(p>0.05)$ similar seminal SOD activity. Seminal catalase of New Zealand White bucks was significantly $(p<0.05)$ different from that of British Spot. However, Fauve de Bourgogne and Chinchilla were statistically similar to British Spot and New Zealand White rabbits. Seminal glutathione peroxidase of New Zealand White bucks was significantly $(p<0.05)$ higher than the three other breeds. Fauve de Bourgogne, British Spot and Chinchilla bucks were not significantly $(p>0.05)$ different in their seminal glutathione peroxidase activity.

\section{Discussion}

Libido (sexual desire) measured in terms of reaction time in seconds and estimated from the time the teaser doe was introduced to the buck's cage up to the point when the buck ejaculated (Daader et al., 1999). Reaction time in the four breeds was similar statistically. However, the range of values obtained in this study $5.40-7.5 \mathrm{~s}$ is lower than $11.49 \mathrm{~s}$ reported in the New Zealand White rabbit by El-Tohamy et al. (2012) and New Zealand White and Baladi rabbits (19.3 and $12.3 \mathrm{~s}$, respectively) reported by Safaa, Emarah, and Saleh (2008) in winter of Egypt. This suggests high sexual urge in this breeds of rabbit at thermal comfort. Bagliacca, Camillo, and Paci

Table 2 Seminal biochemistry of four exotic breeds of rabbit

\begin{tabular}{|c|c|c|c|c|c|c|}
\hline Parameters & Fauve de Bourgogne & Chinchilla & British Spot & New Zealand White & SEM & $p$ value \\
\hline Glucose (mmol/L) & 1.12 & 0.75 & 0.58 & 0.54 & 0.17 & NS \\
\hline Protein (g/L) & $28.80^{\mathrm{ab}}$ & $27.00^{\mathrm{ab}}$ & $39.90^{\mathrm{a}}$ & $12.20^{\mathrm{b}}$ & 3.50 & * \\
\hline Cholesterol (mmol/L) & 0.87 & 1.86 & 0.83 & 0.97 & 0.21 & NS \\
\hline Magnesium (mmol/L) & 1.01 & 1.11 & 1.06 & 1.03 & 0.03 & NS \\
\hline Phosphorus (mmol/L) & $3.91^{\mathrm{a}}$ & $3.74^{\mathrm{a}}$ & $3.25^{\mathrm{b}}$ & $3.26^{\mathrm{b}}$ & 0.23 & * \\
\hline Sodium (mmol/L) & $60.24^{a}$ & $45.56^{\mathrm{b}}$ & $62.01^{\mathrm{a}}$ & $63.88^{a}$ & 7.03 & * \\
\hline Potassium (mmol/L) & 46.42 & 58.68 & 62.15 & 38.56 & 4.89 & NS \\
\hline Chloride (mmol/L) & 0.30 & 0.63 & 0.52 & 0.44 & 0.08 & NS \\
\hline
\end{tabular}

Means in the same row with different superscripts are significantly $(p<0.05)$ different SEM standard error of the mean, NS not significant $(p>0.05)$

*Significant difference $(p<0.05)$ 
Table 3 Seminal oxidative status of four exotic breeds of rabbit

\begin{tabular}{|c|c|c|c|c|c|c|}
\hline Parameters & Fauve de Bourgogne & Chinchilla & British Spot & New Zealand White & SEM & $p$ value \\
\hline Lipid peroxidation (TBARS/mg protein) & $0.03^{b}$ & $0.05^{\mathrm{ab}}$ & $0.07^{\mathrm{a}}$ & $0.06^{\mathrm{a}}$ & 0.01 & * \\
\hline Total antioxidant activity (mmol/litre) & 0.78 & 0.82 & 0.79 & 0.60 & 0.07 & NS \\
\hline Superoxide dismutase (U/min/mg protein) & $57.27^{\mathrm{ab}}$ & $29.09^{b}$ & $48.18^{\mathrm{ab}}$ & $91.82^{\mathrm{a}}$ & 10.87 & * \\
\hline Catalase (nmoles of $\mathrm{H}_{2} \mathrm{O}_{2}$ consumed $/ \mathrm{min} / \mathrm{mg}$ protein) & $345.69^{\mathrm{ab}}$ & $300.43^{\mathrm{ab}}$ & $165.99^{\mathrm{b}}$ & $817.73^{\mathrm{a}}$ & 62.13 & * \\
\hline Glutathione peroxidase ( $\mu \mathrm{gGSH} / \mathrm{min} / \mathrm{mg}$ protein) & $102.85^{\mathrm{b}}$ & $88.27^{b}$ & $61.16^{b}$ & $244.14^{\mathrm{a}}$ & 18.89 & * \\
\hline
\end{tabular}

Means in the same row with different superscripts are significantly $(p<0.05)$ different

SEM standard error of the mean, LTHI least temperature-humidity index, NS not significant $(p>0.05)$, TBARS thiobarbituric acid reactive substances, GSH glutathione

*Significant difference $(p<0.05)$

(1987) reported that the effect of heat stress on spermatogenesis can be observed in the decreased semen quality in autumn, since after heat exposure (in summer), the effects disappear by the end of the third spermatogenetic cycle (Tharwat, Khadr, Amin, Miukawy, \& Kotby, 1994), or more than 70 days are required for recovery. Thus, best ejaculate from bucks could be obtained at thermal comfort, as post treatment effect of heat stress also declines semen quality.

This study is in agreement with the findings of Abd El-Azim and El-kamash (2015) that breed of rabbits bucks differs in reaction time, semen $\mathrm{pH}$, semen density, semen color, mass motility and advanced motility.

Chinchilla rabbits had highest semen volume compared to other breeds, but its lower sperm concentration indicates that its semen output constitutes more of seminal fluid than spermatozoa. This is also evident in lower total motile spermatozoa and live spermatozoa compared to other breeds. British Spot and New Zealand White breeds despite recording a lower semen volume had apparently higher mass motility and individual sperm motility and significantly higher sperm concentration. The superiority of New Zealand White is also reported by Abd El-Azim and El-kamash (2015) that semen ejaculates of New Zealand White is better than Balady and Sinai under the environmental conditions of Egypt.

This corroborates with the findings of El-Tohamy et al. (2012) in which New Zealand White bucks in winter despite having high semen volume $(1.02 \mathrm{ml})$ had lower sperm concentration $2.82 \times 10^{8} / \mathrm{ml}$ and total motile sperm cells $1.99 \times 10^{8} /$ ejaculate. However, the semen volume of $1.02 \mathrm{ml}$ obtained by El-Tohamy et al. (2012) is higher than the range of values obtained in this study (0.34-0.70 ml), but higher sperm concentration and total motile spermatozoa were obtained in this study compared to values obtained in New Zealand White bucks in winter of Egypt. However, the range of semen volume $(0.34-0.70 \mathrm{ml})$ obtained in this study was similar to the result obtained by Safaa et al. (2008) in Baladi and New Zealand White rabbits 0.80 and $0.55 \mathrm{ml}$ under winter conditions of Egypt. The New Zealand White that had better semen quality than other breeds in this study corroborates evidence that the reproductive and productive performances of New Zealand White rabbits reared in Egypt were superior to that of other imported breeds with regard to semen quality and reproductive performance (Daader, Gabr, Khadr, \& Seleem, 2002; Safaa et al., 2008). This could be an inherent trait in this breed due to its low thermal susceptibility (Jimoh \& Ewuola, 2016).

Daader and Seleem (2005) have reported that in rabbits, hypo-osmotic swelling test (HOS test; a measure of functional membrane integrity) is more reliable in assessing the outcome of in vitro fertilization than other semen parameters. This is perhaps the most reliable estimate of structural and functional integrity of the sperm acrosomal and tail membranes. Though, statistically similar values of structural and functional membrane integrity were obtained. British Spot had apparently highest functional membrane integrity $(72.78 \%)$ among the breeds, and New Zealand White had apparently highest structural membrane integrity (99.28\%). Season has a significant effect on sperm abnormalities of New Zealand White bucks (Bodnär, Szendrö, Nemeth, Eiben, \& Radnai, 2000) as demonstrated in Pannon White and New Zealand White bucks, which showed higher ratio of intact spermatozoa in spring and winter (Bodnär et al., 2000), similar to Russian breed (Kadlecik, 1983). Bodnär et al. (2000) reported that Pannon White and New Zealand White males produce less abnormal spermatozoa throughout the year than Angora bucks.

If the suggestion on changes in sperm cells subjected to HOS test indicate a functionally intact plasma membrane is accepted, and that this is necessary for normal spermatozoa function such as motility and fertilization, then, within a semen sample, the more cells with swollen plasma membranes, the better the potential sperm quality (Neild et al., 2000). Daader and Seleem (2005) added that the abrupt drop in osmotic pressure may result in a malfunction in the physiological processes of spermatozoa. It was reported based on HOS test that the reproductive efficiency of Baladi bucks (44.83\%) seems to be greater than that of the New Zealand White rabbit bucks (32.17\%) under winter Egyptian condition 
(Safaa et al., 2008). However, range of values (69.65$72.78 \%)$ obtained in this study is higher than that reported by Safaa et al. (2008) and El-Tohamy et al. (2012) in New Zealand White bucks in winter of Egypt. The evaluation of rabbit spermatozoa functional membrane integrity is a good indicator of the reproductive ability of rabbit bucks (El-Tohamy et al., 2012). Also, the incidence of sperm abnormalities was higher in summer compared with other seasons in ejaculates of Bouscat White and New Zealand White males (Amin, El-Fouly, El-Shobhy, \& El-Sherbiny, 1987).

Kasa and Thwaites (1992) observed significant increases in the ratio of dead and piriform sperm after an increase in the level of heat stress.

Seminal plasma is usually an isotonic neutral medium, and it is a detrimental factor to sperm cell survival (White, 1976). Genetic differences did not affect seminal glucose, cholesterol, magnesium, potassium and chloride in the current study. However, genetic differences were observed in the breeds' seminal protein, sodium and phosphorus. This suggests breed differences in semen biochemical inclusions. The range of seminal protein values $1.22-3.99 \mathrm{~g} / \mathrm{dL}$ observed in this study is lower than the range $2.88-4.50 \mathrm{~g} / \mathrm{dL}$ reported by Attia, Abd El Hamid, Ismaiel, and El- Nagar (2013) in rabbit bucks. Cholesterol efflux from the plasma membrane is required for the cyclic adenosine monophosphatedependent tyrosine phosphorylations that are correlated with sperm capacitation (Visconti et al., 1999). Changes in cholesterol content, phospholipid dynamics and protein mobility are intimately linked to capacitation (Flesch et al., 2001). Several studies have demonstrated that cholesterol inhibited the induction of the acrosome reaction (Davis, 1982) and also inhibits fertilization (inhibits or delays capacitation) in many species including the rabbit (Davis, 1982). The influx of cholesterol also reverses capacitation of sperm; indeed, vesicles from rabbit seminal plasma containing cholesterol and liposomes containing cholesterol render capacitated sperm incapable of fertilizing eggs in vivo (Gerena, Irikura, Urade, \& Eguchi, 1998).

However, it was indicated that one of the most important factors contributing to poor quality semen has been attributed to oxidative stress (Bucak, Sariözkan, \& Tuncer, 2010). The increase in the production of reactive oxygen species ROS determines semen characteristics and sperm-oocyte fusion (Akiyama, 1999). Also, the antioxidant mechanism is necessary to prevent free radical damage to the sperm cell as a result of generation of hydrogen peroxide and the superoxide ion by rabbit spermatozoa (Holland, Alvarez, \& Storey, 1982). The literature on endogenous antioxidant contributions to oxidative stress protection of spermatozoa in the rabbit is scanty. The objective of most experiments was to evaluate the effects of prooxidants or antioxidants on the concentrations of TBARS or on semen quality (Nichi et al., 2006). Genetic differences in breeds were evident in most oxidative stress markers except total antioxidant activity of seminal fluid. New Zealand White had higher antioxidant enzyme activity at this period. However, the buck breeds had the different activity of various antioxidants in response to the antioxidant demand of the system for ROS scavenging, which is evident in low seminal lipid peroxidation. The antioxidant enzyme activity of the rabbits assessed was better than values reported by Jimoh, Ewuola, and Balogun (2017) at the peak of heat stress. This infers that the animals have better antioxidant status at thermal comfort compared to when exposed to heat stress. This claim is buttressed by the low lipid peroxidation recorded in this study compared to Jimoh et al. (2017) values recorded for seminal lipid peroxidation in heat stressed rabbits. It is thus inferred that rabbit oxidative stability which could influence immune status and productivity is better when rabbits are at thermal comfort giving the fact that oxidative stress due to hyperthermia apparently reduces the activity of antioxidant enzymes which could result in impairment of sperm membrane integrity.

\section{Conclusion}

New Zealand White had the best oxidative status across the four breeds, and this enhanced its semen quality parameters. However, British spot bucks had comparable high semen quality as New Zealand White bucks, and seminal biochemical parameters in the breeds were within a similar range.

\section{Abbreviations}

GPx: Glutathione peroxidase activity; LTHI: Least temperature-humidity index; ROS: Reactive oxygen species; SEM: Standard error of mean; SOD: Superoxide dismutase; TBARS: Thiobarbituric acid reactive substance; THI: Temperaturehumidity index

\section{Acknowledgements \\ The authors are grateful to the management and staff of the Rabbitry Unit, Teaching and Research Farm, University of Ibadan, for their assistance in providing animals and housing for this work. Also, Dr. Ajayi Babajide Oluwaseun of Biochemistry Department, BOWEN University, Iwo, Osun State, Nigeria, is appreciated for his technical assistance in oxidative status assay procedures and chemicals used.}

\section{Funding}

The research outcome presented in this article was jointly funded by the authors. This research did not receive any specific grant from any funding agency in the public, commercial or not-for-profit sector.

\section{Availability of data and materials Not applicable}

\section{Authors' contributions}

JOA designed the study, carried out the field work and statistical analysis and wrote the first manuscript. EOE approved the study layout, supervised the research and read and corrected the first manuscript. Both authors read and approve the final manuscript. 


\section{Authors' information}

Jimoh, Olatunji Abubakar, Ph.D. (Registered Animal Scientist; Nigerian Institute of Animal Science)Lecturer and Consultant,

Animal Physiology and Bioclimatology,

Department of Agricultural Technology, Federal Polytechnic Ado Ekiti, Ekiti State, Nigeria.

Email: abubakarjimoh2011@gmail.com

Ewuola Emmanuel Olubisi, PhD. (Registered Animal Scientist; Nigerian Institute of Animal Science).

Senior Lecturer,

Animal Physiology, Toxicology and Reproduction

Animal Physiology and Bioclimatology Unit, Department of Animal Science, University of Ibadan, Oyo State, Nigeria.

Email: eoewuola@gmail.com

\section{Ethics approval and consent to participate}

The study was approved by the institutional committee on the care and use of animals for experiment and in accordance with the $\mathrm{NIH}$ guide for the care and use of laboratory animals.

\section{Consent for publication}

Not applicable

\section{Competing interests}

The authors declare that they have no competing interests.

\section{Publisher's Note}

Springer Nature remains neutral with regard to jurisdictional claims in published maps and institutional affiliations.

\section{Received: 28 May 2018 Accepted: 17 April 2019}

Published online: 17 May 2019

\section{References}

Abd El-Azim, A., \& El-kamash, E. M. (2015). Evaluation of semen quality and its relation to mating system for some breeds of rabbits under environmental conditions in the middle of Egypt. Egyptian Poultry Science, 31(II), 467-480.

Akiyama, M. (1999). In vivo scavenging effect of ethylcysteine on reactive oxygen species in human semen. Nippon HinyokikaGakkaiZasshi, 90(3), 421-428.

Alvariño, J. M. R. (2000). Reproductive performance of male rabbits. In Proc. 7th World Rabbit Congress, (vol. A, pp. 13-35). Valencia.

Amin, S. O., El-Fouly, M. A., El-Shobhy, H. E., \& El-Sherbiny, A. M. (1987). Effect of season, breed and sequence of ejaculation on some physical characteristics of rabbit semen. In Proc. Ist Conference of Agricultural Development Research (vol. I, pp. 54-67). Cairo.

Attia, Y. A., Abd El Hamid, E. A., Ismaiel, A. M., \& El- Nagar, A. (2013). The detoxication of nitrate by two antioxidants or a probiotic, and the effects on blood and seminal plasma profiles and reproductive function of New Zealand White rabbit bucks. Animal, 7(40), 591-601.

Bagliacca, M., Camillo, F., \& Paci, G. (1987). The effect of temperature on the reproductive performance of male rabbits. Rivista di Coniglicoltura, 24(10), 61-65.

Beers, R. F., \& Sizer, I. W. (1952). A spectrophotometric method for measuring the breakdown of hydrogen peroxide by catalase. The Journal of Biological Chemistry, 195, 133-140.

Bodnär, K., Szendrö, Z., Nemeth, B. E., Eiben, C., \& Radnai, I. (2000). Comparative evaluation of abnormal spermatozoa in Pannon White, New Zealand White and Angora rabbit semen. Archives Animal Breeding, 43(5), 507-512.

Bucak, M. N., Sariözkan, S., \& Tuncer, P. B. (2010). The effect of antioxidants on post-thawed Angora goat Capra hircusancryrensis sperm parameters, lipid peroxidation and antioxidant activities. Small Ruminant Research, 89(1), 24-30.

Castellini, C. 2008. Semen production and management of rabbit bucks. 9th World Rabbit Congress. June 10-13, 2008 - Verona - Italy

Daader, A. H., Gabr, H. A., Khadr, A. M. F., \& Seleem, T. S. T. (2002). Fertility traits in different breeds in rabbit does as affected by coitus frequency and remating interval. In Proc: 3rd Sci. Conf. on Rabb. Prod. in Hot Climates, (pp. 253-262). Hurghada.

Daader, A. H., Gabr, H. A., \& Seleem, T. S. (1999). Productive and reproductive performance of New Zealand White and Californian rabbit bucks as affected by supplementing vitamin A to the diet during summer and winter seasons. In Proceeding of 7th Conference on Animal Nutrition Ruminants, Poultry and Fishes, (pp. 55-564). El - Arish.
Daader, A. H., \& Seleem, T. S. T. (2005). Response of spermatozoa of different breeds of rabbits to hypo-osmotic swelling test. In Proc: The $4^{\text {th }}$ Inter. Con. on Rabbit Prod. in Hot Clim, (pp. 177-181). Sharm El-Sheikh.

Davis, B. K. (1982). Uterine fluid proteins bind sperm cholesterol during capacitation in the rabbit. Experientia, 38, 1063-1064.

Ellman, G. (1959). Tissue sulphhydril. Archives of Biochemistry and Biophysics, 82 , 70-77.

El-Sheikh, T. M., \& Seleem, T. S. T. (2010). Effect of genotype and natural or artificial insemination on indigenous and adapted rabbit performance. Scientific papers-animal science series: Lucrări Ştiințifice - Seria Zootehnie, 65, 19-24.

El-Tohamy, M. M., Kotp, M. S. Z., El-Nattat, W. S., Amira, H. M., \& Soliman, S. I. (2012). An attempt at alleviating heat stress infertility in male rabbits with some antioxidants, (pp. 1-7). Cairo: Department of Animal Reproduction, National Research Centre.

Flesch, F. M., Brouwers, J. F., Nievelstein, P. F., Verkleij, A. J., Van Golde, L. M., Colenbrander, B., \& Gadella, B. M. (2001). Bicarbonate stimulated phospholipid scrambling induces cholesterol redistribution and enables cholesterol depletion in the sperm plasma membrane. Journal of Cell Science, $114,3543-3555$.

Ganaie, A. H., Shanker, G., Bumla, N. A., Ghasura, R. S., \& Mir, N. A. (2013). Biochemical and physiological changes during thermal stress in bovines. Journal of Veterinary Science and Technology, 4, 126. https://doi.org/10.4172/ 2157-7579.10001224

Gerena, R. L., Irikura, D., Urade, Y., Eguchi, N., Chapman, D. A., \& Killian, G. J. (1998). Identification of a fertility-associated protein in bull seminal plasma as lipocalin-type prostaglandin D synthase. Biology of Reproduction, 58, 826-833.

Holland, M. K., Alvarez, J. G., \& Storey, B. T. (1982). Production of superoxide and activity of superoxide dismutase in rabbit epididymal spermatozoa. Biology of Reproduction, 27, 1109-1118.

Jimoh, O.A., and Ewuola, E. O. (2016). Thermoregulation response of exotic rabbit breeds during peak temperature humidity index of Ibadan. Tropical Animal Production Investigation 19, (1): 41-47.

Jimoh, O. A., \& Ewuola, E. O. (2018). Thermophysiological traits in four exotic breeds of rabbit at least temperature-humidity index in humid tropics. The Journal of Basic and Applied Zoology, 79(18), 31-39. https://doi.org/10.1186/ s41936-018-0031-9.

Jimoh, O. A., Ewuola, E. O., \& Balogun, A. S. (2017). Oxidative stress markers in exotic breeds of rabbit during peak of heat stress in Ibadan, Nigeria. Journal of Advances in Biology and Biotechnology, 12(1), 1-9. https://doi.org/10.9734/ JABB/2017/30437.

Kadlecik, O. (1983). The effect of season and inbreeding on semen quality in rabbits. Acta Zootechnica, 39, 303-309.

Kasa, I. W., \& Thwaites, C. J. (1992). Semen quality in bucks exposed to $34{ }^{\circ} \mathrm{C}$ for 8 hours on either 1 or 5 days. Journal of Applied Rabbit Research, 15, 560-568.

Koracevic, D., Koracevic, G., Djordjevic, V., Andrejevic, S., \& Cosic, V. (2001). Method for the measurement of antioxidant activity in human fluids. Journal of Clinical Pathology, 54, 356-361.

Lindner, H. R., \& Mann, T. (1960). Relationship between the content of androgenic steroids in the tests and the scenetory activities of the seminar vesicle on the bull. Journal of Endocrinology, 21, 341-360.

Lowry, O. H., Rosebrough, N. J., Farr, A. G., \& Randall, R. J. (1951). Protein measurement with folinepherol reagent. The Journal of Biological Chemistry, 193, 255-273.

Marai, I.F.M., Ayat, M.S., \& Abd El-Monem, U.M. (2001). Growth performance and reproductive traits at first parity of New Zealand white female rabbits as affected by heat stress and its alleviation, under Egyptian conditions. Tropical Animal Health and Production, 33:1-12.

Moce, E., Vicente, J. S., Lavara, F., Lavara, R., \& Marco-Jiménez, F. (2004). Differences in the response of the spermatozoa from three rabbit lines to the hypo-osmotic swelling test. Reproduction in Domestic Animal, abstract, 39(4), 265.

Neild, D. M., Weild, D. M., Chaves, M. G., Flores, M., Miragaya, M. H., Gonzalez, E., \& Agüero, A. (2000). The HOS test and its relationship to fertility in the stallion. Andrologia, 32, 351-355.

Nichi, M., Bols, P. E. J., Zuge, R. M., Barnabe, V. H., Goovaerts, I. G. F., Barnabe, R. C., \& Cortada, C. N. M. (2006). Seasonal variation in semen quality in Bosindicus and Bostaurus bulls raised under tropical conditions. Theriogenology, 66, 822-828.

Ohkawa, H., Ohishi, N., \& Yagi, K. (1979). Assay for lipid peroxides in animal tissues by thiobarbituric acid reaction. Analytical Biochemistry, 95, 351-358. 
Rotruck, J. T., Pope, A. L., Ganther, H. E., Swanson, A. B., Hafeman, D. C., \& Hoekstra, W. G. (1973). Selenium: biochemical roles as a component of glutathione peroxidase. Science., 179, 588-590.

Safaa, H. M., Emarah, M. E., \& Saleh, N. F. A. (2008). Seasonal effects on semen quality in Black Baladi and White New Zealand rabbit bucks. World Rabbit Science, 16, 13-20.

Tharwat, E. E., Khadr, A. F., Amin, S. O., Miukawy, M. Y., \& Kotby, E. (1994). Effect of hot environment on the reproductive performance of New Zealand White rabbit. Cahiers Options Mediterraneennes, 8(SUPPL), 613-618.

Trevisan, M., Browne, R., Ram, M., Muti, P., \& Freudenheim, J. (2001). Correlates of markers of oxidative status in the general population. American journal of epidemiology, 154, 348-356.

Visconti, P. E., Ning, X., Fornes, M. W., Alvarez, J. G., Stein, P., Connors, S. A., \& Kopf, G. S. (1999). Cholesterol efflux mediated signal transduction in mammalian sperm: cholesterol release signals an increase in protein tyrosine phosphorylation during mouse sperm capacitation. Developmental Biology, 214, 429-443.

White, I. G. (1976). Reproduction in the male. In Veterinary Physiology. J.G. Phillis Bristol: Wright-Scientechnica. United Kingdom

Williams, C. A., Kronfeld, D. S., Hess, T. M., Saker, K. E., \& Waldron, J. N. (2002). Antioxidant supplementation and subsequent oxidative stress of horses during an 80-km endurance race. Journal of Animal Science, 82, 588-594.

\section{Submit your manuscript to a SpringerOpen ${ }^{\odot}$ journal and benefit from:}

- Convenient online submission

- Rigorous peer review

- Open access: articles freely available online

High visibility within the field

- Retaining the copyright to your article

Submit your next manuscript at $\boldsymbol{\nabla}$ springeropen.com 